Dept. of Food Hygiene,

Faculty Veterinary Medicine, Cairo University, Egypt

\title{
EFFECT OF SOME CHEMICAL SANITIZERS ON MICROBIAL QUALITY OF DAIRY FARM MILK
}

(With 6 Tables and 3 Figures)

By

\author{
SALWA A. ALY; S.D. MORGAN; HODA A. ZAKI* \\ and DOAA A. MAHROUSE*
}

*Animal Research Institue, Dokki, Giza, Egypt

(Received at 15/9/2008)

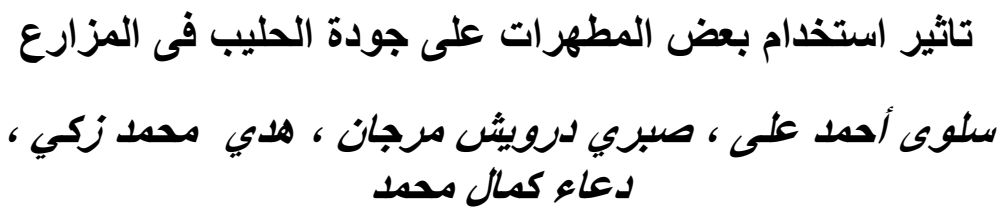

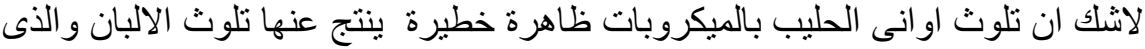

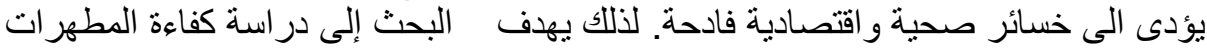

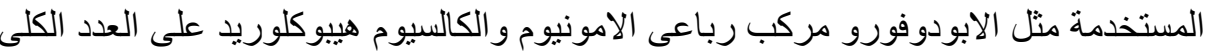

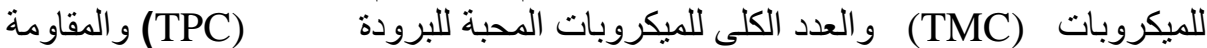

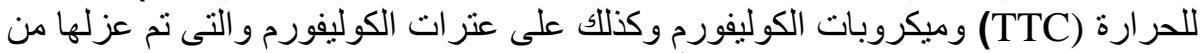

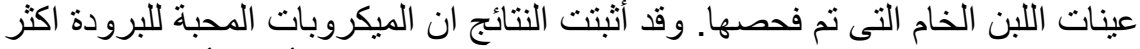

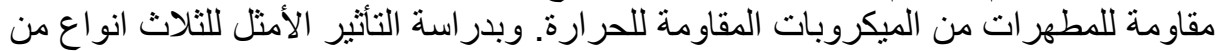

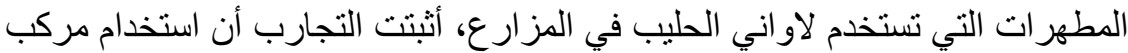

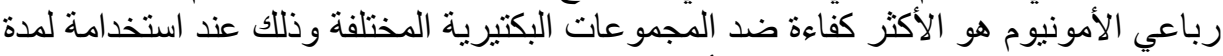

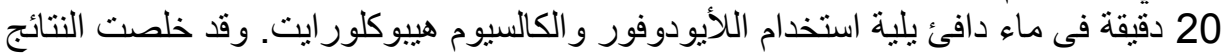

الى ان مقاومة الميكروبات للمطهرات المختلفة تجعلنا نخطط لاستخدام الاكثر كفاءة للقضاء التهاء عليها فى او انى الحليب. اليكروبات

\section{SUMMARY}

Biofilm formation on milk equipment is a well-known phenomenon and it has caused pollution, safety hazards and substantial economic loss. This study was undertaken to examine the efficacy of the sanitizers including iodophore, quaternary ammonium compounds and calcium hypochlorite against total mesophilic count (TMC), total psychrophilic count (TPC), total thermoduric count (TTC) and total coliform count MPN/ $\mathrm{ml}$ of the examined raw milk samples. Additionally the sanitizers were also tested against Escherichia coli strains isolated from the 
examined milk samples. The result shows that psychotrophic bacteria were more resistant on sanitizer used than thermoduric bacteria. Among the three commercially sanitizer tested, quaternary ammonium compound was the most potent against microorganisms after $20 \mathrm{~min}$ exposure time using warm water. However, calcium hypochlorite and iodophore showed a lower effect on the bacterial groups. The resistance of Escherichia coli strains to the sanitizer was strain dependent. It was concluded that the resistances of microbes to different sanitizers should be taken into account when planning the cleaning of milking equipment.

Key words: Milk, dairy farms, iodophore, calcium hypochlorite, quaternary ammonium compounds

\section{INTRODUCTION}

Bacterial contamination can adversely affect the quality, functionality and safety of milk and dairy products produced by the dairy industry. When contamination of milk occurs evidence suggests that biofilms on the surfaces of milk processing equipment are a major source. During milk storage undesirable deposits, consist mainly of protein and minerals, are formed on the milking equipment surface. These protein and mineral rich deposits provide a good ground for bacteria to settle and grow (Flint et al., 1997; Peng, et al., 2002; Taormina and Beuchat, 2006).

Over the last years, foodborne diseases caused millions of illnesses worldwide (Dontorou et al., 2003; Castonguay et al., 2006). One way in which milk can be contaminated with pathogens is by contacting contaminated milk-processing equipment. Therefore, it is of the utmost importance to clean and disinfect these milk equipment regularly and sufficiently to provide consumers with wholesome and safe product (Rombouts and Abee, 2002; Dunsmore et al., 2006; Hagel et al., 2008).

Efficient sanitation is required in food plants where wet surfaces provide favorable conditions for microbial growth (Peng et al., 2002). Sanitizers used in the food processing industry include oxidizing agents, e.g. hypochlorite, hydrogen peroxide, ozone, iodophore and quaternary ammonium compounds (Kumar and Anand, 1998; Lang et al., 2000; Lomander et al., 2004; Myung et al., 2007). The sanitizers must be effective, safe and rinsable, as well as easy to use, and they should not affect the sensory qualities of the product (Larson et al., 1991). 
The most practical hygienic program is the use of sanitizer to eliminate transient bacteria from the dairy equipment. The purpose of sanitizing is to kill residual microorganisms present on these surfaces immediately prior to milking. All milking equipment, lines, and utensil surfaces that come into contact with milk or dirt or manure must be thoroughly cleaned and sanitized before the next milking. Inadequate or improper cleaning or sanitizing or both allows bacteria to remain on equipment surfaces and to grow and multiply (McDdonnell, and Denver, 1999; Wirtanen et al., 2001; Dufour et al., 2004; Wiszniewska and Szteyn, 2006). Although chemical companies tend to push new and innovative cleaning sanitizers, there is little published research on the relative effectiveness of different chemical sanitizers and an apparent lack of techniques that can simply and effectively determine their effectiveness. Therefore the purpose of this study was to compare the relative effectiveness of iodophore, calcium hypochlorite and quaternary ammonium compound against total mesophilic, total psychrophilic, total thermoduric and coliform count as well as the efficacy of the sanitizers against Escherichia coli strains isolated from the examined raw milk under conditions typical of those encountered in dairy manufacturing plants.

\section{MATERIALS and METHODS}

\section{Collection of samples}

Fresh raw cow milk samples were collected from two different dairy farms herds at Giza governorate. Samples were collected manually using hand milking $(100 \mathrm{ml}$ each). The samples directly added to milking bottles as described by Helke et al. (1993). The bottles were soiled with raw milk on both sides and then air dried, untreated and served as (control), while the other bottles were treated as follows: sanitizer treatment with either cold water (with exposure time 10 minutes (T1); with exposure time 20 minutes (T2) and warm water at $40^{\circ} \mathrm{C}$ with exposure time 10 minutes (T3); with 20 minutes exposure time (T4). These steps were all performed at room temperature. All the experiments in this study were performed three times. The sanitizers used were: iodophor (50-70 mg / liter of free iodine); quaternary ammonium compounds, (150-250 mg / liter) and calcium hypochlorite (200-250 ppm available chlorine) a product intended for use in the dairy milk industry. They were made as commercially recommended by manufacturer and used immediately after preparation. The milk samples 
were transferred directly to the laboratory with a minimum of delay for microbiological examination.

\section{Microbiological analysis}

Milk samples of all treatments were examined for some microbial groups including: Total mesophilic count (T.M.C.) according to APHA (1993); total psychrophilic count (T.P.C.) according to Cox and MacRae (1998); total thermoduric count (T.T.C.) according to Desmasures and Gueguen, (1997); coliform count "MPN" according to ICMSF (1986) as well as isolation and serological identification of the isolated coliforms strains according to Krieg and Holt (1986).

The efficiency of the detergents used on the growth of the isolated Escherichia coli strains

The bacteriocidal effect of the commercially available detergents on the isolated $E$. coli serotypes was applied by adding $1 \mathrm{ml}$ of cell suspension to $10 \mathrm{ml}$ disinfectant solution maintained at $20^{\circ} \mathrm{C}$ after 10 and $20 \mathrm{~min}$ of exposure time. Cell suspension was mixed with $10 \mathrm{ml}$ of sterile distilled water and served as control. One $\mathrm{ml}$ of the mixture was spread onto a tryptone soy agar plate (TSA, Oxoid Ltd.) and incubated at $37^{\circ} \mathrm{C}$. Colonies were counted after 48 hours according to Anonymous (1998).

\section{Bacterial suspension preparation}

Prior to the experiment loopfull of the each culture strain was inoculated in $10 \mathrm{ml}$ of tryptone soy broth (Oxoid Ltd) and incubated at $37 \mathrm{C}$ for 20 hours. After incubation, the broth was spread on a tryptone soy agar tube (Oxoid Ltd) at 37C for 20-24 h. Cells were suspended in tryptone sodium chloride solution (TSC) in order to obtain $1.0 \times 10^{9}$ to $3.0 \times 10^{9} \mathrm{CFU} / \mathrm{ml}$. Concentration was determined by optical absorbance at $405 \mathrm{~nm}$ according to Anonymous (1998).

\section{Statistical analysis}

Analysis of variance (ANOVA) was performed using the General Lineal Models Procedure of SAS- System (Statistical Analysis Systems Institute, 1999) were conducted on the log transformed data to determine if any significant differences $(\mathrm{p}<0.05)$ lay between the treatments and the control. Significant differences between means were determined using least square means (LS means). The Means were calculated by using a Statistical Analysis System (SAS Institute, 1999). 


\section{RESULTS}

Table 1: Statistical analytical results of bacteriological examination in the examined milk samples mean $\log _{10} \mathrm{cfu} / \mathrm{ml}$ using Iodophore

\begin{tabular}{|c|c|c|c|c|c|c|c|c|c|}
\hline \multirow{2}{*}{ Bact.exam. } & \multirow{2}{*}{ Control } & \multicolumn{2}{|c|}{ T1 } & \multicolumn{2}{|c|}{ T2 } & \multicolumn{2}{c|}{ T3 } & \multicolumn{2}{c|}{ T4 } \\
\cline { 3 - 10 } & & $\log$ & $\%$ & $\log$ & $\%$ & $\log$ & $\%$ & $\log$ & $\%$ \\
\hline T.M.C. & 9.9 & 4.8 & 51.52 & 3.8 & 61.62 & 3.7 & 62.63 & 3.6 & 63.64 \\
\hline T.P.C. & 7.7 & 3.7 & 51.95 & 3.6 & 53.25 & 3.4 & 55.84 & 3.5 & 54.55 \\
\hline T.T.C. & 7.9 & 3.7 & 53.16 & 3.7 & 53.16 & 3.2 & 49.59 & 3.0 & 62.03 \\
\hline MPN & 7.7 & 4.4 & 42.86 & 2.4 & 68.83 & 2.3 & 70.13 & 1.7 & 77.92 \\
\hline
\end{tabular}

Table 2: Statistical analytical results of bacteriological examination in the examined milk samples mean $\log _{10} \mathrm{cfu} / \mathrm{ml}$ using quaternary ammonium compounds

\begin{tabular}{|c|c|c|c|c|c|c|c|c|c|}
\hline \multirow{2}{*}{$\begin{array}{l}\text { Bact.exam } \\
\text { • Control }\end{array}$} & \multicolumn{2}{|c|}{ T1 } & \multicolumn{2}{|c|}{ T2 } & \multicolumn{2}{c|}{ T3 } & \multicolumn{2}{c|}{ T4 } \\
\cline { 3 - 10 } & & $\log$ & $\%$ & $\log$ & $\%$ & $\log$ & $\%$ & $\log$ & $\%$ \\
\hline T.M.C. & 9.8 & 3.60 & 63.27 & 3.59 & 63.38 & 3.38 & 65.51 & 3.46 & 64.69 \\
\hline T.P.C. & 8.6 & 3.70 & 56.98 & 3.64 & 57.67 & 3.39 & 60.58 & 3.44 & 60.00 \\
\hline T.T.C. & 8.9 & 3.56 & 60.00 & 3.49 & 60.79 & 2.98 & 66.52 & 2.94 & 66.97 \\
\hline MPN & 6.9 & 3.30 & 52.17 & 2.54 & 63.19 & 1.30 & 81.52 & 1.11 & 83.91 \\
\hline
\end{tabular}

Table 3: Statistical analytical results of bacteriological examination in the examined milk samples mean $\log _{10} \mathrm{cfu} / \mathrm{ml}$ using calcium hypochlorite

\begin{tabular}{|c|c|c|c|c|c|c|c|c|c|}
\hline \multirow{2}{*}{ Bact.exam } & \multirow{2}{*}{ Control } & \multicolumn{2}{|c|}{ T1 } & \multicolumn{2}{c|}{ T2 } & \multicolumn{2}{|c|}{ T3 } & \multicolumn{2}{c|}{ T4 } \\
\cline { 3 - 11 } & & $\log$ & $\%$ & $\log$ & $\%$ & $\log$ & $\%$ & $\log$ & $\%$ \\
\hline T.M.C. & 8.88 & 3.7 & 58.33 & 3.63 & 59.12 & 3.57 & 59.98 & 3.36 & 62.16 \\
\hline T.P.C. & 7.69 & 3.6 & 53.19 & 3.53 & 54.1 & 3.38 & 56.05 & 3.52 & 54.23 \\
\hline T.T.C. & 7.9 & 4.68 & 40.76 & 3.62 & 54.18 & 3.39 & 57.09 & 3.45 & 56.33 \\
\hline MPN & 7.24 & 2.8 & 61.33 & 2.78 & 61.6 & 1.87 & 74.17 & 1.38 & 80.94 \\
\hline
\end{tabular}

Table 4: Bactericidal effect of iodophor on the isolated Escherichi coli serotypes.

\begin{tabular}{|c|c|c|c|c|c|}
\hline \multirow{2}{*}{ E. coli serotypes } & Control & \multicolumn{2}{|c|}{ T1 } & \multicolumn{2}{|c|}{ T2 } \\
\cline { 3 - 6 } & Log & $\log$ & $\%$ & $\log$ & $\%$ \\
\hline $\mathrm{O}_{26}$ & 9 & 5.52 & 71.1 & 0 & 100 \\
\hline $\mathrm{O}_{128}$ & 9 & 5.22 & 74.4 & 0 & 100 \\
\hline $\mathrm{O}_{148}$ & 9 & 5.60 & 86.7 & 0 & 100 \\
\hline $\mathrm{O}_{166}$ & 9 & 4.7 & 75.9 & 0 & 100 \\
\hline
\end{tabular}


Table 5: Bactericidal effect of Q.A.C. on the isolated Escherichia coli serotypes.

\begin{tabular}{|c|c|c|c|c|c|}
\hline \multirow{2}{*}{$\begin{array}{c}\text { E. coli } \\
\text { serotypes }\end{array}$} & Control & \multicolumn{2}{|c|}{$\mathrm{T} 1$} & \multicolumn{2}{c|}{$\mathrm{T} 2$} \\
\cline { 3 - 6 } & $\log$ & $\log$ & $\%$ & $\log$ & $\%$ \\
\hline $\mathrm{O}_{26}$ & 9 & 0 & 100 & 0 & 100 \\
\hline $\mathrm{O}_{128}$ & 9 & 0 & 100 & 0 & 100 \\
\hline $\mathrm{O}_{148}$ & 9 & 0 & 100 & 0 & 100 \\
\hline $\mathrm{O}_{166}$ & 9 & 0 & 100 & 0 & 100 \\
\hline
\end{tabular}

Table 6: Bactericidal effect of $\mathrm{Ca}$. hypochlorite on the isolated Escherichia coli serotypes.

\begin{tabular}{|c|c|c|c|c|c|}
\hline \multirow{2}{*}{$\begin{array}{c}\text { E. coli } \\
\text { serotypes }\end{array}$} & Control & \multicolumn{2}{|c|}{$\mathrm{T} 1$} & \multicolumn{2}{c|}{$\mathrm{T} 2$} \\
\cline { 3 - 6 } & $\log$ & $\mathrm{Log}$ & $\%$ & $\mathrm{Log}$ & $\%$ \\
\hline $\mathrm{O}_{26}$ & 9 & 3.9 & 43.3 & 0 & 100 \\
\hline $\mathrm{O}_{128}$ & 9 & 4.56 & 50.7 & 0 & 100 \\
\hline $\mathrm{O}_{148}$ & 9 & 5 & 55.6 & 0 & 100 \\
\hline $\mathrm{O}_{166}$ & 9 & 3.7 & 41.1 & 0 & 100 \\
\hline
\end{tabular}

Fig. 1: Statistical analytical results of bacteriological examination after using iodophor.

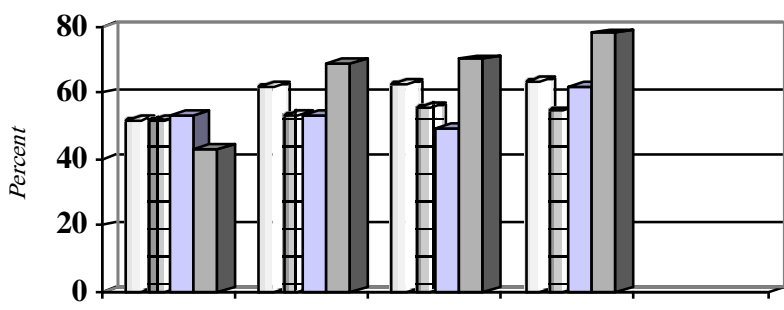

T10 W10

$\square$ T.C.C. $\square$ T.P.C. $\square$ T.T.C. $\square$ M.P.N. 
Fig. 2: Statistical analytical results of bacteriological examination after using Q.A.C

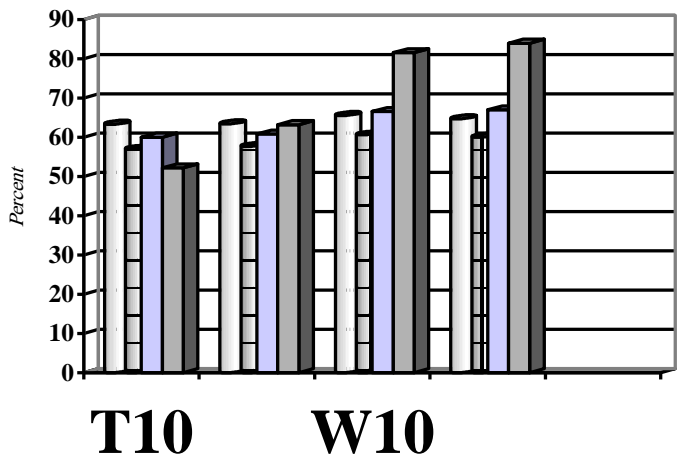

口 T.C.C. 口 T.P.C. 口 T.T.C. 口 M.P.N.

Fig. 3: Statistical analytical results of bacteriological examination after using calcium hypochlorite

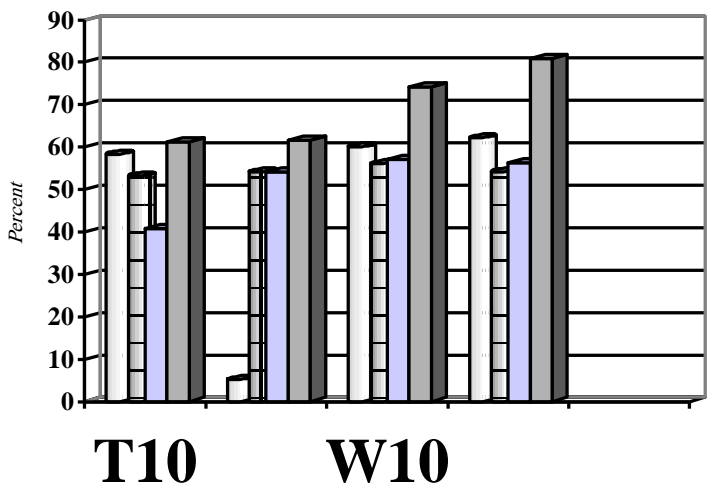

口 T.C.C. $\square$ T.P.C. $\square$ T.T.C. $\square$ M.P.N.

\section{DISCUSSION}

The effectiveness of our sanitizing program was determined against total mesophilic count (TMC), total psychrophilic count (TPC), total thermoduric count (TTC) and coliform count (MPN) in the examined raw milk samples. The use of iodophore achieved a mean log reduction of $4.8,3.7,3.7 \& 4.4 ; 3.8,3.6,3.7 \& 2.4 ; 3.7,3.4,3.2 \& 2.3$ and 
3.6, 3.5, 3 and $1.7 \mathrm{cfu} / \mathrm{ml}$ milk using $\mathrm{T} 1, \mathrm{~T} 2, \mathrm{~T} 3$ and $\mathrm{T} 4$ respectively as compared to the control samples (Table 1 \& Fig. 1). There was a significant difference $(\mathrm{P}>0.05)$ between the control and the treated milk samples but no significant difference $(\mathrm{P}<0.05)$ between $\mathrm{T} 1, \mathrm{~T} 2, \mathrm{~T} 3$ and T4 respectively. Warm water appeared to have little additional impact on cell numbers. Nearly similar results were reported by Suárez and Ferreirós (1991) and Boulange et al., (2004). Higher results were recorded by Magrex-Debar et al., (2000); Wirtanen et al., (2001); Orden et al., (2002). and Peng et al., (2002) and microorganisms become more resistant to sanitizers and other antimicrobial agents when they are attached to milking surface (Stone and Zottola, 1999; Wirtanen et al., 2001). The bacterial cells were very resistant and even 20 minutes exposure time with warm water was not able to effectively eliminate the microbial population. The different antimicrobial efficacies of iodophore among the bacterial groups may be due to its limited penetration into the biofilms (Myung et al., 2007).

It is clear from the results recorded in Table (2) \& Fig (2) that use of quaternary ammonium compounds gave a mean log reduction of TMC, TPC, TTC and MPN count 3.6, 3.7, $3.56 \& 3.3$; 3.59, 3.64, 3.49 $\& 2.54 ; 3.38,3.39,2.98 \& 1.30$ and $3.46,3.44,2.94$ and $1.11 \mathrm{cfu} / \mathrm{ml}$ milk for T1; T2; T3 and T4 respectively. There was a significant difference $(\mathrm{P}>0.05)$ between the control and the treated samples. It was clear that on increasing exposure time for 20 min leading to increase the reduction of MPN count. Nearly similar finding were recorded by Suárez and Ferreirós (1991).

Results illustrated in Table (3) and Fig. (3) proved that use of Calcium hypochlorite gave a mean log reduction in the microbial groups TMC, TPC, TTC and MPN count 3.7, 3.6, $4.68 \& 2.8 ; 3.63,3.53,3.62$ $\& 2.78 ; 3.57,3.38,3.39 \& 1.87$ and $3.36,3.52,3.45 \& 1.38 \mathrm{cfu} / \mathrm{ml}$ milk sample for T1; T2; T3 and T4 respectively. There was significant difference between the control samples and all the treatment $(\mathrm{P}>0.05)$. The coliform count was highly decreased on increasing the exposure time with warm water. The results agree, to a certain extent, with those reported by Girgis et al., (1999) and Wirtanen, et al., (2001). The obtained results declared that the use of quaternary ammonium compound was the most effective in reduction of total mesophilic, total psychrophilic, total thermoduric and coliform count, followed by calcium hypochlorite and iodophor. The use of iodophor and calcium hypochlorite had a lower effect than quaternary ammonium compound on lowering the total thermoduric count. The reduced accessibility of 
the bacterial cells to the different sanitizers may be due to the interfering action of the substances in contact with the bacteria (Ntsama-Essomba, et al., 1997; Sundheim et al., 1998). The cells associated with the biofilms have the ability to form exopolysaccharide (EPS) matrix which surrounds the biofilm and protect the bacteria from sanitizers (James et al., 1995; Gibson et al., 1999). The variability in effectiveness with the used sanitizers in eliminating bacteria is not surprising as a large number of factors can influence their effectiveness including the: composition, concentration, nature and age of the contaminated surface; temperature, time of exposure, degree of water hardness and the characteristics of the surface being cleaned (Austin and Bergeron, 1995; Stewart and Seiberling, 1996; Changani I 1997; Wong, 1998; Storgards et al., 1999; Faille et al., 2001; Lelievre et al., 2001, Lelievre et al., 2002a; Lelievre et al., 2002b; Boulange et al., 2004; Dufour et al., 2004). In general while sanitizers such as chlorine, iodophores and quaternary ammonium compounds have proven to be effective against bacteria their effectiveness against bacterial biofilms is variable (Mosteller and Bishop, 1993, Rossoni and Gaylarde, 2000; Bremer et al., 2002).

The quality of raw milk has been considerably improved by the refrigeration on farms, and in processing plants. Unfortunately, the current sanitizing practices for the raw milk favored the growth of psychrotrophic bacteria, which are able to grow below $7^{\circ} \mathrm{C}$ during cold storage (Munsch and Alatossava, 2006). It was reported that psychrotorophs can grow and produce heat stable protease enzyme which breakdown casein, and in turn cause milk spoilage (Plock, 1994; Esther et al., 2004; Maurilio et al., 2006). Presence of thermophilic bacteria in the milk after cleaning and sanitizing milking equipment become a serious problem because the spores of this organism often exhibit a high resistance to heat treatment. The vegetative cells is capable of growth at $65^{\circ} \mathrm{C}$ and produce proteolytic enzymes which reduce the shelf life time of heat treated milk and other dairy products (Jeurnink, 1991; Zottola, and Sasahara, 1994; Peng, et al., 2002; Jin- Ah Yoo, et al., 2006).

Table (4) shows the reduction of Escherichia coli strains O26, O128, O148 and O166 in the suspension after 10 and 20 minutes exposure time to iodophore. The population reduction was $61.3,58,62.2$ $\& 52.2 \%$ and 100,100,100 \& 100 respectively. The use of quaternary ammonium compounds was completely effective to inactivate Escherichia coli strains in both 10 and 20 minutes exposure time (Table 5). Calcium hypochlorite was unable to inactivate Escherichia coli 
serotypes after 10 minutes exposure time while completely inactivate them after 20 minutes exposure time (Table 6). The lesser effectiveness of iodophore and hypochlorite against the Escherichia coli strains in the present study, was in agreement with Mattila et al., (1990) Gibson, et al., (1999); Pompermayer, and Gaylarde, (2000) and Augustin et al., (2004). On the other hands, Mosteller and Bishop (1993) found that the efficacy of sanitizers including iodophor, hyphohlorite, and quaternary ammonium compound versus the suspensions of Escherichia coli strains resulted in a >5.0 log-cycle reduction while the same concentrations were relatively ineffective against the attached cells. Frank and Koffi (1998) have observed that planktonic cells of E. coli decrease by more than 6.0 cycles after 30-s exposure to iodophore. Mustapha and Liewen (1989) have indicated that $E$. coli is more resistant to the lethal action of sodium hypochlorite on a stainless steel surface than in vitro. From the results recorded, it is clear that the use of Quaternary ammonium compound was the most effective and significant $(\mathrm{P}>0.05)$ in the reduction of different Escherichia coli serotypes, followed by Iodophor and Calcium hypochlorite. Sodium hypochlorite and quaternary ammonium compound (QAC) are used widely as sanitizers in food industries. As a strong oxidizing agent, hypochlorite is known to be very active in killing most bacteria, fungi and viruses. QAC are hydrophilic, cationic molecules. It was reported that QAC readily adsorb to bacterial surface, which is hydrophilic and negatively charged, penetrate the cell wall, and disrupt the cytoplasmic membrane (Natero and Levine, 1995; Peng et al., 2002; Wilfido et al., 2006). The choice of sanitizer or cleaning agent along with the time of action is very important when destroying microbes.

Escherichia coli serotypes have a great public health importance. It is capable of inducing gastro-intestinal illness among young children with severe cholera-like syndrome and shigella-like symptoms. Therefore their presence in milk represent a public health hazard for consumers (Natero and Levine, 1995; Ntsama-Essomba, et al., 1997; Faille et al., 2003; Bremer et al., 2006).

\section{REFERENCES}

APHA, "American Public Health Association" (1993): Standard Methods for Examination of Dairy Products. $14^{\text {th }}$ Ed., American Public Health Association, Wahington, D.C. 
Anonymous (1998): Chemical disinfectants and antiseptics-quantitative suspension test for evaluation of bactericidal activity of chemical disinfectants and antiseptics used in food, industrial, domestic and institutional areas - test method and requirement (phase 2 step 1). UNE-EN-1276, pp. 1-35.

Augustin, M.; Vehmas, T. and Atroshi, F. (2004): Assessment of enzymatic cleaning agents and disinfectants against bacterial biofilms. J. Pharm Sci. 18, 7(1): 55-64.

Austin, W. and Bergeron, G. (1995): Development of bacterial biofilms in dairy processing lines, J. Dairy Res. 62 (3): 509-519.

Bremer, P.J.; Fillery, S. and McQuillan, A.J. (2006): Laboratory scale Clean-In-Place (CIP) studies on the effectiveness of different caustic and acid wash steps on the removal of dairy biofilms. Int J. Food Microbiol. 15 (3) 254-262.

Bremer, P.J.; Monk, I. and Butler, R. (2002): Inactivation of Escherichia coli spp. biofilms using chlorine: impact of substrate, $\mathrm{pH}$, time and concentration, Lett. Appl. Microbiol. 35: 321-332.

Boulange, C.; Jullien, P.E.; Dubois, T.; Benezech, A. and Faille, T. (2004): The influence of surface chemistry on the hygienic status of industrial stainless steel, Biofouling 20 (1) 25-33.

Castonguay, MH.; Van der Schaaf, S.; Koester, W.; Krooneman, J.; Van der Meer, W.; Harmsen, H. and Landini, P. (2006): Biofilm formation by Escherichia coli is stimulated by synergistic interactions and co-adhesion mechanisms with adherenceproficient bacteria. Res. Microbiol. 157(5): 471-478.

Changani, C.; Belmar-Beiny, T. and Fryer, P.T. (1997): Engineering and chemical factors associated with fouling and cleaning in milk processing, Exp. Therm. Fluid Sci. 14 (2): 392- 406.

Cox, M. and MacRae, C. (1998): Growth of Psychrotrophic bacteria in raw and heat treated milk. Journal of Applied Bacteriology 74 (20 403-407.

Desmasures, N. and Gueguen, M. (1997): Monitoring the microbiology of high quality milk by monthly sampling over 2 years. Journal of Dairy Research 64 (1) 271-280.

Dontorou, C.; Papadopoulou, C.; Filioussis, G.; Economou, V.; Apostolou, I. and Zakkas, G. (2003): Isolation of Escherichia coli O157:H7 from milk in Greece. Food Microbiol., 82 (2) 273-279. 
Dufour, M.; Simmonds, R. and Bremer, P. (2004): Development of a laboratory scale clean-in-place system to test the effectiveness of "natural" antimicrobials against dairy biofilms, J. Food Prot. 67: 1438-1443.

Dunsmore, F.; Planchon, S.; Bellon, F. and Talon, R. (2006): Formation of biofilm by Staphyloccocus xylosus. Int. J. Food Microbiol. 109 (1-2): 88-98.

Esther, N.; Aaku, E.; Collison, K.; Berhanu, A. and Sisai, M. (2004): Microbiological quality of milk from two processing plants in Gaborone Botswana. J. Environ Quality 56 (3): 790-797.

Faille, C.; Fontaine, F.; Lelièvre, C. and Bénézech, T. (2003): Adhesion of Escherichia coli, Citrobacter freundii and Klebsiella pneumoniae isolated from milk: consequence on the efficiency of sanitation procedures. Water Sci.Technol. 47(5): 225-231.

Faille, C.; Fontaine, F. and Benezech, T. (2001): Potential occurrence of adhering living bacillus spores in milk product processing lines, J. Appl. Microbiol. 90 (3): 892-900.

Flint, F.; Frank, J. and Chmielewski, R. (1997): Effectiveness of sanitation with quaternary ammonium compound or chorine on stainless steel and other domestic food-preparation surfaces. J. Food Prot. 60 (1): 43-47.

Frank, S. and Kofi, H. (1998): The effect of practical conditions on the efficacy of disinfectants. Int. Biodeterioration and Biodegradation 41 (3-4): 177-183.

Gibson, H.; Taylor, J.; Hall, K.E. and Holah, J.T. (1999): Effectiveness of cleaning techniques used in the food industry in terms of the removal of Coliform biofilms. J. Appl. Microbiol. 87: 41-48.

Girgis, E.; Abdelghany, I.; Laila, M, Yousef and Laila, M. Mohamed (1999): Bactericidal effect of some pretreatments of raw milk on its keeping quality. Egyptian J. Dairy Sci. 27 (1) 59-70.

Hagel, L.; Gunter, J. and Gail, S. (2008): Cleaning and sanitization. In: Hand Book of Process Chromatography. $2^{\text {nd }},: 147-159$.

International Commette On Microbiological Specification For Foods, I.C.M.S.F., (1986): Microorganisms in Food. Their significance and methods on enumeration $2^{\text {nd }}$ Ed. Univ. of Toronto Presses. Toronto, Buffalo/ London.

James, G.A.; Beaudette, L.; and Costerton, J.W. (1995): Interspecies bacterial interactions in biofilms. J. Ind. Microbiol. 15: 257262. 
Jeurnink, J.M. (1991): Effect of proteolysis in milk on fouling in heat exchangers. Netherland Milk Dairy Journal 45 (1): 23-32.

Jin-Ah Yoo, M.; Hardin, X. and Dong, C. (2006): The influence of milk composition on the growth of Bacillus stearothermophilus. Journal of Food Engineering 77: 96-102.

Krieg, N.T. and Holt, J.G. (1986): Bergs Manual of Systemic Bacteriology. Vol 2, Williams and Wilkins, Baltimore, Academic press London, p. 244-300.

Kumar, C.G. and Anand, S.K. (1998): Significance of microbial biofilms in food industry, Int. J. Food Microbiol. 42 (1): 9-15.

Lang, M.; Ingham, H. and Ingham, S. (2000): Effecacy of novel organic acid and hypochlorite treatments for eliminating Escherichia coli from milk. Int J. Food Microbiol 58 (1-2): 73-82.

Larson E.L.; Morton, H.E. and Block, S.S. (1991): Disinfection, Sterilisation and Preservation. In: Disinfection, Sterilization and preservation (Larson E.L.; Morton, H.E. and Block, S.S. Eds). $2^{\text {nd }}$ Ed. Academic Press London, p. 204- 260.

Lelievre, C.; Faille, C. and Benezech, T. (2001): Removal kinetics of Bacillus cereus spores from stainless steel pipes under CIP procedure: influence of soiling and cleaning conditions, J. Food Process Eng. 24 (2): 359-379.

Lelievre, C.; Antonini, G.; Faille, C. and Benezech, T. (2002a): Cleaning-in-place-modelling of cleaning kinetics of pipes soiled by bacillus spores assuming a process combining removal and deposition. Food Bioprod. Process. 80 (3): 305311.

Lelievre, C.; Legentilhomme, P.; Gaucher, C.; Legrand, J.; Faille, C. and Benezech, T. (2002b): Cleaning in place: effect of local wall shear stress variation on bacterial removal from stainless steel equipment, Chem. Eng. Sci. 57: 1287-1297.

Lelievre, P.; Legentilhomme, C.; Gaucher, J.; Legrand, C.; Faille and Benezech, T. (2002a): Cleaning in place: effect of local wall shear stress variation on bacterial removal from stainless steel equipment, Chem. Eng. Sci. 57: 1287-1297.

Lindsay, D.; Brozel, S.; Mostert, J. and Holy, V. (2002): Differential efficacy of a chlorine dioxide-containing sanitizer against single species and binary biofilms of a dairy-associated Bacillus cereus and a Pseudomonas fluorescens isolate, J. Appl. Microbiol. 92: 352-361. 
Lomander, T.; Park, H. and Chung, D. (2004): Effects of chloride and $\mathrm{pH}$ on efficacy of electrolyzed water for inactivating Escherichia coli O157:H7 and Listeria monocytogenes. Int. Food Microbiol., 91: 13-18.

Mattila, T.; Manninen M.; Kyläsiurola, A.L. (1990): Effect of cleaningin-place disinfectants on wild bacterial strains isolated from a milking line. J. Dairy Res.; 57(1):33-39.

Magrex-Debar, E.L.; Lemoine, J.; Gelle, M.; Jacquelin, L. and Choisy, C. (2000): Evaluation of biohazards in dehydrated biofilms on foodstuff packaging. Int. J. Food Microbiol. 55 (2): 239-243.

McDdonnell, G. and Denver, R. (1999): Antiseptics and disinfectants: activity, action, and resistance. Clinical Microbiology Review, 12: 147-179.

Maurilio, L.; Martins, C.; Pinto, L.; Rodrigo, B.; Rocha, E. and Maria, C. (2006): Genetic diversity of Gram-negative, proteolytic, psychrotrophic, bacteria isolated from refrigerated raw milk. Int. J. Food Microbiol. 111 (2): 144-148.

Mosteller, Y. and Bishop, J. (1993): Sanitizer efficacy against attached bacteria in a milk biofilm. J. Food Prot. 56 (1): 34-41.

Mustapha, A. and Liewen, M.B. (1989): Destruction of Escherichia coli by sodium hypochlorite and quaternary ammonium sanitizers. J. Food Prot. 52: 306-311.

Munsch, A.P. and Alatossava, T. (2006): Phenotypic characterization of raw milk-associated psychrotrophic bacteria. Microbiological Research 161 (5): 334-346.

Myung, W.; Jang, H.; Hyum, J.; Dong, K. and Cheorun, J. (2007): Effects of irradiation and sodium hypochlorites on the microorganisms attached to a commercial food container. J. Food Microbiol. 24 (3): 544-548.

Natero, A. and Levine, M. (1995): Escherichia coli diseases in human. In: Escherichia coli in domestic animals and human. $3^{\text {rd }} \mathrm{Ed}$. (Glyes, G.L. ed.) Academic Press London, p. 200-289.

Ntsama-Essomba, C.; Bouttier, S.; Ramaldes, M.; Dubois-Brissonnet, F. and Fourniat, J. (1997): Resistance of Escherichia coli growing as biofilms to disinfectants. Vet. Res. 28(4):353-363.

Orden, J.A.; Cid, D.; Ruiz-Santa-Quiteria, J.; Garcı, S.; Martı'nez, S. and de la Fuente, R. (2002): Verotoxin-producing Escherichia coli (VTEC) enteropathogenic E. coli (EPEC) and necrotoxigenic E. coli (NTEC) isolated from healthy cattle in Spain. Journal Appl. Microbiol., 93: 29-35. 
Peng, S.; Tsai, W. and Chou, C. (2002): Inactivation and removal of bacterial contamination by sanitizer and detergent. Int. J. Food Microbiol. 77 (1): 11-18.

Plock, J. (1994): Denaturierung von Molkenprotein in Molkenkonzentrate und auf die Ausbildung thermisch induzierter Gelstructuren. PhD. Thesis. Technische Universita" $t$ München, Germany.

Pompermayer, D. and Gaylarde, C. (2000): The influence of temperature on the adhesion of mixed cultures of Staphylococcus aureus and Escherichia coli to sanitizers. Food Microbiol. 17 (2): 361-365.

Rombouts, G. and Abee, Y. (2002): Emerging foodborne pathogens. Int. J. Food Microbiol., 78 (1): 31-41.

Rossoni, E.M. and Gaylarde, C. (2000): Comparison of sodium hypochlorite and iodophore as sanitising agents for stainless steel food processing surfaces using epifluorescence microscopy, Int. J. Food Microbiol. 61 (1): 81-85.

Statistical Analysis Systems Institute, SAS (1999): User's Guide. Version 8. Cary, NC: USA: Institute Inc.

Stewart, C. and Seiberling, D.A. (1996): The secrets out: clean in place, Chem. Eng. 103: 72-79.

Stone, L.S. and Zottola, E.A., (1999): Microbial biofilms in the food processing industry-Should they be a concern. Int. J. Food Microbiol. 28 (1): 125-148.

Storgards, E.; Simola, H.; Sjoberg, A.M. and Wirtanen, G. (1999): Hygiene of gasket materials used in food processing equipment part 2: Aged materials, Food Bioprod. Process. 77: 146-155.

Suárez, B. and Ferreirós C.M. (1991): Psychrotrophic flora of raw milk: resistance to several common disinfectants. J. Dairy Res. 58 (1): 127-136.

Sundheim, S.; Langsrud, E. and Heir, A. (1998): Bacterial resistance to disinfectant containing quaternary ammonium compound. International Biodeterioration and Biodegradation 41 (3): 235239.

Taormina, P. and Beuchat, L. (2006): Survival of Listeria monocytogenes in commercial food-processing equipment cleaning solutions and subsequent sensitivity to sanitizers and heat. Journal Appl. Microbiol., 92 (1): 71-80. 
Wilfido, J.; Artur, X.; Roig, M.; Manuella, H.; Toma, L. and Buenaventura, G. (2006): Bactericidal efficacy of sanitizers against pathogenic and non pathogenic strains of Staphylococcus, Listeria and Escherichia coli. Food Control 17 (3): 516-521.

Wirtanen, G.; Salo, S. and Mattila-Sandholm, T. (2001): Removal of foodborne Biofilms- comparison of surface and suspension tests part I. Lebensmittel-Wissenschaft \& Technologie, 25 (1): 4349.

Wiszniewska, A. and Szteyn, J. (2006): Resistance of bacteria isolated from milking equipment to disinfectants. Rocz Panstw Zakl Hig. 57(1): 17-21.

Wong, C.L. (1998): Biofilms in food processing environments, J. Dairy Sci. 81(12): 2765-2770.

Zottola, E.A. and Sasahara, K.C. (1994): Microbial biofilms in the food processing industry-Should they be a concern. Int. J. Food Microbiol. 23 (1): 125-148. 